\title{
PROTECTION OF THE RIGHTS AND FREEDOM OF CITIZENS IN THE CONTEXT OF THE MAIN FUNCTION OF THE STATE
}

Sokolenko O. L.

\section{INTRODUCTION}

As you know, according to Part 2 of Art. 3 of the Constitution of Ukraine of June 28, 1996 No. 254k / 96-VR, human rights and freedoms and their guarantees determine the content and orientation of the state's activities ${ }^{1}$. The above emphasizes the special place of human rights as a guide in shaping the state mechanism and practice of state building. At the same time, it is obvious that human rights are of equal importance for the development of the individual as a full-fledged member of civil society. Of key importance in this case is the reality of human rights, which, at the level with the legal recognition of such rights and the effective mechanism for their realization, also provides for the effectiveness of judicial and administrative protection, which is understood in science by the fact that "judicial and administrative decisions have come into force and implemented, that is, necessarily led to the restoration or compensation of violated rights and freedoms “ ${ }^{2}$.

At the same time, considering the various aspects of the administrative and legal mechanism of protection of human rights as one of the elements of ensuring their reality, which, in turn, is a kind of indicator of the development of a modern legal socially oriented state, it is necessary to pay special attention to the still existing contradictions of methodological nature in understanding the essence of human and citizen's rights and freedoms. In particular, it is about establishing the specific category of the citizen's rights, its relation to the rights, freedoms and interests of the individual and the citizen, which is directly related to the doctrinal and normative-legal definition of the content of the rights of citizens as an object of administrative and legal protection.

It should be noted that the problems of the legal status of a person and a citizen were given attention within several branches of law (the theory of law, constitutional, international, administrative law, etc.), first of all, in the works of such scientists as K.G. Volynka ${ }^{3}$, A. M. Kolodiy and A. Yu. Oliynyk ${ }^{4}$,

${ }^{1}$ Конституція України: від 28.06.1996 р., № 254к/96-ВР // ВВР України. - 1996. № 30. - Ст. 141.

2 Турута О.В. Юридичний механізм забезпечення реальності прав і свобод громадян / О.В. Турута // Форум права. - 2010. - № 2. - С. 519-523 [Електронний ресурс]. Режим доступу: http://www.nbuv.gov.ua/e-journals/FP/2010-2/10tovicg.pdf.

${ }^{3}$ Волинка К. Забезпечення прав і свобод особи в Україні: теоретичні і практичні аспекти / К. Волинка // Право України. - 2000. - № 11. - С. 30-34. 
P.M. Rabinovich ${ }^{5}$ and others. At the same time, these studies mainly focus on the conceptual basic foundations of human rights, unjustifiably neglecting the specific features of citizens' rights in terms of their protection mechanisms. Against this background, the issues of the concept and essence of citizens' rights as an object of administrative and legal protection are considered relevant.

First of all, it should be noted that human and citizen's rights are only one manifestation of their legal status, and apart from the latter, they cannot characterize the specifics of personal relations with the state and civil society. In particular, this is clearly stated in the fundamental principle of "noobligation rights". However, there is no doubt that legal status cannot be limited to the rights and obligations of the individual, including other elements that ensure the reality of such rights and obligations, the proper level of alignment of the public interests of different individuals and social groups.

Thus, the elucidation of the essence of human rights and the citizen should be made taking into account their place in the general structure of legal status and the nature of the relationship between the rights, obligations and other elements of the legal status of the human and citizen. At the same time, it should be noted that such a legal status as a coherent category is also influenced by a generally unified social status of the individual, which is the most comprehensive category and is not limited to purely legal content. Thus, in sociology, the social status of the individual is defined as his position in the social system, related to belonging to a particular social group or community, the totality of his social roles and the quality and degree of their fulfillment.

In our view, it is impossible to identify all the essential features of legal status, and therefore of human and citizen rights, without a comprehensive study of all parties to such a phenomenon as status. Thus, a philosophical understanding of status indicates that it is the social, relative position (position) of an individual or group in a social system that is determined by a number of characteristics specific to such a system. Political science also refers to the category of status and defines it as a set of rights and responsibilities that determine the legal status of a person, government body or international organization; "Comprehensive indicator of the position of a particular community, group or individuals in the social system, one of the most important parameters of social stratification" ${ }^{6}$.

So, to summarize, let us summarize that, first, status always reflects a certain position (position) of a person in a society or collective, and secondly, it includes at least such elements as rights and obligations. Legal status is a

${ }^{4}$ Колодій А.М. Права людини і громадянина в Україні: навч. посіб. / А.М. Колодій, А.Ю. Олійник. - К.: Юрінком Інтер, 2003. - 336 с.

5 Рабінович П.М. Основні права людини: поняття, класифікації, тенденції / П. М. Рабінович // Український часопис прав людини. - 1995. - № 1. - С. 14-23.

${ }^{6}$ Політичний енциклопедичний словник / за ред. Ю.М. Шемчушенка, В.Д. Бабкіна. К.: Юрінком Інтер, 1997. - С. 400. 
much narrower category than social status, which appropriately affects the scope of those rights that will constitute the content of such status.

At the same time, in our opinion, in terms of the legal expression of a person's legal status, attention should be paid not only and not so much to the technical consolidation of its content in certain legal acts, but also in general to the legal nature of such status. Important, though not universally acknowledged, is that law (including rights expressed in legal norms), based on the theory of natural law and Roman ethical doctrine on which the modern Romano-German legal system is based, does not have its own logo, which is brought into law by ethics as a practical philosophy ${ }^{7}$. Thus, human and citizen rights, as an element of legal status, do not simply reflect the legal will of the legislator, but, above all, are the objective result of natural social and legal development.

Note that the essence of the legal status of man and citizen in science, as a rule, is revealed through the content of its structure. In our opinion, at the level with the elements of the legal status of a person and a citizen, a set of features that characterize both the legal status as a whole and its specific element, in particular, human and citizen rights, should be singled out. It should be noted at the outset that forms of legal expression of legal status, first of all, namely human and citizen's rights, are not limited to only legal acts, but also include other sources, such as a legal treaty, a judicial precedent, etc. Moreover, based on the provisions of Art. 19, 21 of the Constitution of Ukraine $^{8}$, under which no one can be compelled to do what is not provided by law and human rights and freedoms are inalienable and inviolable, there is every reason to assert that the concept of natural law is accepted by the legal system of Ukraine. provides as a condition for the validity of human rights the obligation of their legal fixation.

However, on the other hand, it is an indisputable positive recognition of such a sign of the legal status of a person and citizen as a guarantee by the state reflecting the latter's obligation to ensure the content of such a legal status, which includes, among other things, the appropriate mechanism and forms of protection of human rights and citizen. This is also actualized by the fact that other scholars guarantee the protection of human rights and citizens not as a principle, but solely as one of the elements of legal status. Thus, V.V. Kravchenko ${ }^{9}$ identifies a separate constitutional and legal institute of guarantees of legal status, and he defines the legal status of the individual somewhat abstractly as his legally entrenched position in the state and society, as an important component of the social status of a person characterizing

${ }^{7}$ Радбрух Г. Філософія права / Г. Радбрух; пер. Є. Причепій, В. Приходько. К.: Тандем, 2006. - 316 с.

${ }^{8}$ Конституція України: від 28.06.1996 р., № 254к/96-ВР // ВВР України. - 1996. № 30. - Ст. 141 .

${ }_{9}^{9}$ Кравченко В.В. Конституційне право України: навч. посіб. / В.В. Кравченко. Вид. 4-е, випр. та доп. - К.: Атіка, 2007. - 568 с. 
personality traits with the state and state-organized society. In our view, it is appropriate to identify the subsidiary nature of guarantees regarding human and citizen rights, which is conditioned by the need for the state to purposely ensure the reality of such rights.

At the same time, the above definition, like the vast majority of other definitions of legal status, does not reflect the specific place occupied by human and citizen rights. At the same time, to ascertain the position of rights in the structure of legal status objectively requires the definition of all its elements, the set of organized relationships of which and constitutes the legal status itself.

First of all, we propose to distinguish legal personality as the primary basis, general condition and basis for the existence of other elements of the legal status of a person and a citizen. Certainly, the acquisition and realization of rights requires legal capacity and appropriate capacity. At the same time, it is not yet universally acknowledged that in the structure of the legal personality, apart from the mentioned elements, the ability of a person to be responsible for the exercise of his rights and the performance of duties, but such torture makes possible the existence in the legal status of a person of such element as legal liability.

In addition, it is rather ambiguous, in our opinion, to identify in the structure of the legal status of a person at the same time his principles and guarantees. Thus, the essence and content of the principles, as well as the guarantees of legal status, are determined, first of all, by human rights, the need to ensure their effective implementation.

Citizenship, which is defined as a stable legal connection of an individual with the state, as a result of which they acquire mutual rights and obligations, in the context of the characteristics of the general structure of legal status may be compared with the categories of legal personality and rights and obligations. Yes, citizenship, as well as legal personality, is the basis for the acquisition of the relevant rights and obligations, but in itself, it already provides for certain rights and obligations. Thus, although citizenship is a rather peculiar legal connection of a person with the state, however, like other socially regulated social relations (for example, marriage), it is objectified in legal status precisely in the form of specific rights and obligations. or special types of capabilities.

Moreover, citizenship is not a completely invariant part of a person's legal status and, unlike human rights principles, can change substantially depending on the individual's will or territory. However, such features as the legal expression and connection of the individual with the state, society, its individual groups or members are already covered by the above definition of legal status. 
Thus, legal personality, legal principles and guarantees, legal liability are in one way or another related, above all, to the rights and obligations as the central categories of the legal status of the individual, aimed at ensuring their completeness and reality. Accordingly, we must note the ambiguity in science regarding the understanding of the essence and concept of such a category as human rights. However, this is due, among other things, to differing views on the formulation of such a definition, given the need to adapt the definition of individual rights in relation to a specific specific legal field. At the same time, such a generality in the approach to the definition of the essence of the rights of the individual does not allow to distinguish them from freedoms and legitimate interests, since it does not contain sufficiently distinctive features. The above definition reflects a basic understanding of individual rights as a measure of possible behavior that changes under the influence of social factors and responds to it, and draws attention to the universal and equal rights of individuals, which is one of the guarantees of individual rights. Thus, in this case, such important features as formal certainty, legal certainty, and official nature of the measure of possible behavior, which directly reflect in their totality the legal essence of individual rights, are presented. Although, on the other hand, even in the aspect of the narrowed administrative-legal status of a citizen, one cannot agree with such a sign of human rights as the permissibility of possible behavior of a person.

It should be noted that according to Part 1 of Art. 19 of the Constitution of Ukraine ${ }^{10}$ establishes the principle that no one can be compelled to do what is not provided by law. At the same time, his perception of something that is not explicitly prohibited by law will be somewhat limited. Administrativelegal relations are characterized by legal inequality of the parties and have power and administrative character, however, this does not mean that absolutely all rights of participants of such relations should also acquire certain properties. The concept of the natural origin of human rights, as mediated in Art. 21, 22 of the Constitution of Ukraine, the Universal Declaration of Human Rights of December 10, $1948^{11}$ and other international legal acts, indicates that human rights are a measure not so much of a state's permissible behavior, but rather of the very nature of possible behavior. Some of these natural rights find their further expression in relevant administrative and legal relations, such as the natural right to participate in the management of state affairs (Article 38 of the Constitution of Ukraine ${ }^{12}$ ). Therefore, even with respect to the rights of the individual, even in terms of the administrative

${ }^{10}$ Конституція України: від 28.06.1996 р., № 254к/96-ВР // ВВР України. - 1996. № 30. - Ст. 141 .

11 Загальна декларація прав людини: від 10.12 .1948 р. // Офіційний вісник України. - 2008. - № 93. - Ст. 3103.

№ $30 .-$ Ст. 141 .

${ }^{12}$ Конституція України: від 28.06.1996 р., № 254к/96-ВР // ВВР України. - 1996. - 
and legal field, it is always a measure of possible behavior, which does not always require its permission from the state, the purpose of which is to provide a legal corridor for the implementation of a certain right. Moreover, as Kravchenko notes, the state should not be limited by the legal fixation of human rights, but instead should provide them not only with legal, but also with economic, political and cultural means. Thus, in the part of administrative and legal protection of the rights of the individual, it is about providing the state not just their abstract reality, but reality within the relevant specific legally formulated and socially justified and justified limits, within which the protection of such rights may be required. This feature is fully consistent with the concept of the natural origin of human rights discussed above, as well as the social conditionality of the rights and obligations of the individual, which take place in his relationship with other persons, social groups, the state and society as a whole. However, the multifaceted nature of this social phenomenon means the embodiment in the category of individual rights not only legal content, but also moral, political and philosophical content. At the same time, in our opinion, it is incorrect to distinguish only some single component of the essence of a person's rights (for example, a legal one), since the complexity and the consistent interrelationships of these factors reflect a true understanding of the category of personality rights.

Note that understanding individual rights as a multifaceted social phenomenon is important in terms of explaining it on the one hand, complex nature, and on the other hand, the place in the structure of social interaction and communication. In addition, such a comprehensive vision of human rights helps to distinguish individual rights from other social opportunities of individual behavior.

For example, a certain politically justified and justified expedient, devoid of legal content, does not in itself create the rights of a person; because, as noted above, the right is not autonomous and self-sufficient. At the same time, in Ukraine, whose legal system is still based on the ideas of legal positivism, there is a widespread technical and legal understanding of law, and therefore of human rights, which places the criterion of their legislative consolidation in the first place. Thus, all this should be taken into account in the formation and practical implementation of the system of administrative and legal protection of individual rights.

Noteworthy is the widely held position in science on the distinction between human rights in objective and subjective terms. On the one hand, it seems quite logical to extend the universal approach to the distribution of the right to objective and subjective human rights. However, it should be borne in mind that this is an objective and subjective legal law, that is, a law originating from the state. Instead, as we have stated above, a substantial layer of individual rights belongs to his or her natural rights, which, to the same extent 
as subjective legal law, require appropriate safeguards and protection, including in the administrative and legal order. Therefore, at the level of subjective human rights based on objective positive law, it is quite appropriate to distinguish subjective natural rights, which do not exist by virtue of a legal norm, but derive from the very nature of man and the life of society. We believe that such an algorithm is unduly complicated, while subjective natural rights of the individual should act as a full object of administrative and legal protection, regardless of their normative expression in the current legislation. Also, in support of the above, the position of the Constitutional Court of Ukraine of 02.11.2004 in the decision No. 15-rp / 2004 that «the right is not limited only by the legislation as one of its forms, but also includes other social regulators, in particular, norms morals, traditions, customs, etc., which are legitimized by society and predetermined by the historically achieved cultural level of society» ${ }^{13}$. On this basis, the objects of administrative and legal protection include those rights of the person, which are directly determined and expressed by the law, regardless of its specific form.

At the same time, individual rights are not completely independent, complete category and exist in the system of logical relations with legal personality, duties and other elements of the legal status of the individual. However, on the other hand, such indivisibility of the legal status of a person necessitates the need to consider not so much a person's rights in an objective sense, as his legal status as a whole (and also in an objective sense). Therefore, in view of the above, we can confidently state that in the context of administrative and legal protection of the individual, one must distinguish between legal status in the objective sense as a coherent category, subjective legal rights, as well as subjective natural rights; the reality of the latter, to which the aim of administrative and legal protection is precisely determined by the content of the former.

It is also necessary to distinguish subjective rights of the individual from the process of their realization. It should be noted that in this case, in fact, different subjective law and its use as a form of right-wing realization are actually identified. We emphasize that the implementation of rights is intended to ensure the implementation of the rules of law in life (legal status in the objective sense), including through the use (right realization) of subjective rights. That is, in a purely theoretical perspective, a state-protected act to exercise the ability of a particular individual to exercise a certain conduct goes beyond subjective law itself. However, for the sake of systematic administrative and legal protection of individual rights, it is necessary to take into account that protection is not only recognized as a person's ability to act

${ }^{13}$ Рішення Конституційного Суду України у справі про призначення судом більш м'якого покарання: від 02.11.2004 р., № 15-рп/2004 // Офіційний вісник України. - 2004. № 45. - Ст. 2975. 
in a certain way, but also his real ability to realize such opportunities available to him, which is appropriately included in the object. administrative and legal protection.

First of all, in this case, not only are the already substantiated characteristics of human rights already emphasized, but also their purpose in meeting the needs of the individual within the statutory limits is quite appropriate. Thus, the limits of the exercise of individual rights are important to protect them to the extent that their non-observance deprives the individual of the right to claim and protect their rights. In view of this, human rights, as an object of administrative and legal protection, act not only as a certain legally guaranteed possibility of behavior, but as an opportunity that is guaranteed by a person the right to satisfy his social needs in accordance with the law and order established in society and the state; providing the state with reality within the relevant specific legally formulated and socially justified and justified limits; the inseparability of subjective legal and natural rights from the process of their realization (use); protection by the state of individual rights.

It should be noted that the above list of features of personality rights is, of course, not exclusive and expresses, first of all, the essence of individual rights precisely as an object of administrative and legal protection. Accordingly, protection, including in the administrative and legal order, is one of the elements of ensuring the reality of the rights of the individual as a key component of his social position aimed at meeting the social needs of the individual in his relations with other persons, the state and society as a whole.

We also emphasize that in science, at the level with the rights of the individual, it is customary to highlight his freedoms and interests. However, the problem of distinguishing the rights, freedoms and interests of the individual is not only theoretical but also practical. In particular, for example, Part 5 of Art. 55 of the Constitution of Ukraine ${ }^{14}$ provides for the right of everyone to "protect their rights and freedoms from violations and unlawful encroachments" by any means not prohibited by law. Thus, both rights, freedoms and legitimate interests, in essence, serve as separate specific objects of administrative and legal protection.

At the same time, unlike the rights of the individual, the category of human and citizen's freedoms is much less scientifically developed, among other things, due to the fact that, according to some scientists, the question of the demarcation of rights and freedoms in the aspect of the legal status of the individual is not fundamental, and they themselves substantively identical. In our opinion, in this case it is really impossible to overlook the single essence of human rights and freedoms as a measure of a certain possible behavior of the individual, however, one cannot agree with the view that rights and

${ }^{14}$ Конституція України: від 28.06.1996 р., № 254к/96-ВР // ВВР України. - 1996. № $30 .-$ Ст. 141. 
freedoms do not have any significant distinct differences. We believe that as a criterion for the delineation of the rights and freedoms of a person and a citizen, there should be a way of realizing a person and providing the state with such possible behavior.

From these positions, the rights of the person should be regarded as such aspirations to enjoy certain social benefits, the effective practical implementation of which requires an active purposeful activity of the state to guarantee and ensure the reality of this variant of possible behavior of the individual. An example of such rights is the constitutional right of a person to work, strike, rest, appropriate social protection (Articles 43-46 of the Constitution of Ukraine ${ }^{15}$ ).

Establishing the essence of the category of individual liberty also requires specific examples. Therefore, freedom of thought and speech, freedom of worldview and religion, freedom of creativity, envisaged by Art. 34, 35, 54 of the Constitution of Ukraine. The aforementioned possibilities, by the way of their realization, do not directly imply permanent state support activity, in other words, they may be exercised on condition that their state is not interfered with in their realization, which should provide the same noninterference by other persons or social institutions. At the same time, we should emphasize the peculiarities of the legislative technique that determine the formulation of the above-mentioned freedoms of the individual, in particular, regarding freedom of thought and speech and freedom of world outlook and religion. The Constitution of Ukraine stipulates that a person has the right to such freedoms. Thus, in this case, there is a peculiar combination of human rights and freedoms, which, in our opinion, is primarily due to certain historical and political factors, given the need for additional protection of the freedoms of the individual. In the legal field, for example, a person's right to freedom of thought and expression should be understood as a stateguaranteed opportunity for the person to think independently and independently of one's views, which, as a particular value of civil society, requires additional protection and protection from the state.

Thus, while the reality of human and citizen freedoms, unlike individual rights, is not so closely linked to the creation of conditions by the state for their realization, it, in turn, requires that the state be restrained and that other persons and social institutions be kept away from it. interference with the personal sphere of human freedom. That is why individual freedoms, as well as their rights, also need adequate protection, including in the administrative and legal order, however, somewhat in another plane, to ensure non-interference with the exercise of such freedoms.

${ }^{15}$ Конституція України: від 28.06.1996 р., № 254к/96-ВР // ВВР України. - 1996. № $30 .-$ Ст. 141 . 
It should be noted that the relation between the rights of the individual and his interests, similar to the considered specifics of human and citizen's rights and freedoms, also remains rather ambiguous from the standpoint of understanding interests as an independent object of legal protection. To some extent, this is due to the fact that in the science of legitimate interest, there are generally fundamentally opposite views on the essence of the category of interest. From the above it is indisputable to deduce at least one thing - that interest in its essence represents a certain need of personality. However, on the other hand, one cannot agree with the simple identification of subjective rights and freedoms of man and citizen, which was more characteristic of Soviet law. In this regard, we draw attention to the fact that the subjective right in the first place is the opportunity to enjoy certain benefits, which may not always be supported by the corresponding real desire of the person to do so (for example, active suffrage). In turn, legitimate interests directly reflect the already formed and real existing relevant aspirations of the individual.

Another, no less significant, distinction between a legitimate interest and a person's right is distinguished in the reasoning part of the decision of the Constitutional Court of Ukraine No. 18-rp / 2004 of 01.12.2004: interest, "even under the protection of law or law, as opposed to subjective law, has no such legal capacity as the latter, because it is not secured by the legal obligation of the other party "16. Consequently, the category of legitimate interest, compared to the rights of a person, is characterized by a much lower degree of legal certainty and is only conditioned by the general content of objective law, which significantly complicates the protection of such legitimate interests. Thus, in the aspect of administrative and legal protection of personal rights, legitimate interest, as well as subjective law, is under the legal protection of the state, moreover, in accordance with the said decision of the Constitutional Court of Ukraine No. 18-rp / 2004 of $01.12 .2004^{17}$, it is an independent object of judicial protection and other remedies. However, in our opinion, legitimate interest, while not part of the content of the rights of the individual, but exists in parallel with it, they may coincide or flow into each other. Therefore, we consider it appropriate and appropriate to consider legitimate interests within the framework of administrative and legal protection of individual rights, which will facilitate a more complete and comprehensive investigation of the system of protection of individual rights, in particular in the activities of law enforcement agencies.

A separate issue is the relationship between the rights of the individual in general and the rights of the citizen as an object of administrative and legal

${ }^{16}$ Рішення Конституційного Суду України у справі про охоронюваний законом інтерес: від 01.12.2004 р., № 18-рп/2004 // Офіційний вісник України. - 2004. - № 50. Ст. 3288.

${ }^{17}$ Ibid. 
protection. In this regard, it should be noted immediately that Art. 55 of the Constitution of Ukraine ${ }^{18}$ establishes the principle of protection of the rights not only of citizens, but also of all other persons, namely foreign citizens and stateless persons. At the same time, the term "person" in its meaning encompasses not only the concept of an individual, but also a legal entity, the issue of the protection of rights of which goes beyond the scope of our research.

Therefore, one should refer to the category of "citizen's rights", although there are several approaches to science in its understanding at once. The first of these is based on an additional element of a person's legal status - citizenship, which constitutes his or her permanent political and legal connection with a particular state. In this case, this term will not include foreigners and stateless persons, but who are equal with the citizens of Ukraine in the right to protection. Therefore, in terms of administrative and legal protection of individual rights, it is more appropriate to follow a second approach to understanding citizens' rights. We emphasize that in the part of administrative and legal protection it is necessary to speak a language, first of all, about the protection of the rights of citizens, that is, both citizens of Ukraine, foreigners and stateless persons. It is this broad generalized understanding of the category of citizens' rights that, on the one hand, denotes the rights (and freedoms) of all individuals, regardless of their nationality, and on the other hand, encompasses not only those special rights stipulated by the relevant public-legal status of the individual, but also its natural rights, that is, human rights.

In our opinion, beyond the protection of the rights of citizens, remedies may serve not so much the specificity of the infringed law as the competence of the respective law enforcement agency, which would ensure the completeness of consideration and resolution of issues of protection of citizens' rights, as well as the implementation of the adopted in this regard. solutions.

Thus, the rights, freedoms and legal interests owed to citizens of Ukraine, foreigners and stateless persons as a basic element of their legal status, provided with appropriate guarantees from the state, are the object of administrative and legal protection. The administrative and legal mechanism of protection plays an important role in ensuring the reality of such citizens' rights as one of the key factors for the formation of the rule of law and the development of civil society in Ukraine.

Today, the protection of citizens' rights is understood as one of the indispensable features of the modern state, ensuring the reality of human and citizen's rights and freedoms is a kind of indicator of the maturity and maturity of such a state. Certainly, this position is the result of the gradual formation of state-legal views towards the recognition of human rights, freedoms and

${ }^{18}$ Конституція України: від 28.06.1996 р., № 254к/96-ВР // ВВР України. - 1996. № 30. - Ст. 141. 
legitimate interests of the highest social value, a guideline in the activities of the state and all public institutions.

Humanistic theories of civil society, natural law, social and democratic state, as well as the rule of law, play an important role in this. It should be noted that the latter is a qualitatively new model of the state, the basis of which is the priority of human and citizen's rights and freedoms, their reality, the provision of sufficient and adequate legal means, the state guarantee. Thus, the protection of human and citizen's rights and freedoms is conceived as one of the key activities of the rule of law, its pivotal function, which permeates the essence of the whole array of public, including state-power, relations.

In this regard, the constitutional foundations of the state system in Ukraine clearly state that Ukraine is not only a sovereign and independent, democratic, social, but also a rule of law (Article 1 of the Constitution of Ukraine of June 28, 1996 No. 254k / 96- $\mathrm{BP}^{19}$ ). At the same time, the practical implementation of this constitutional norm of a declarative nature is substantially complicated by the contradictions of the state government, the fragmentation of legal regulation and the lack of sufficient political will to build a truly rule of law in Ukraine. First of all, we will note that the ideas that underpin the concept of the rule of law today have been developed since ancient times and to this day. On the one hand, this has led to the formation of a more or less holistic view of such a phenomenon as a rule of law and, in particular, an understanding of the protection of citizens' rights as its defining feature. However, on the other hand, it also results in the current and to this day controversy regarding approaches to the perception of the diversity of the rule of law, which in turn affects the definition of the place of protection of citizens' rights in the substantive expression of the rule of law. In addition, the current problem of the relation of the rule of law with the democratic state, the welfare state and civil society cannot be overlooked. The above shows its importance in terms of the characteristics of the category of human and citizen's rights and freedoms, the substantiation of their leading role in the modern rule of law, the protection of which is understood as one of the main duties of such a state.

Today, the general features of the state as a political organization of society by theorists of law include, first of all, the existence of public power, territory, sovereignty, apparatus of government, apparatus of coercion, taxation, etc. Indeed, considering the state solely from the standpoint of institutional and formal criteria, protection of human rights cannot be considered as an indispensable feature in general of any state that emerges in the course of its evolution as a result of changes in the system of social relations itself.

${ }^{19}$ Конституція України: від 28.06.1996 р., № 254к/96-ВР // ВВР України. - 1996. № $30 .-$ Ст. 141. 
The rule of law is a qualitatively new social phenomenon on par with the state in general, which is manifested also in the aspect of protection of human and citizen's rights and freedoms. It should be noted that considering the state as a historically changing phenomenon whose features and functions change with each new socio-economic formation (civilization), the protection of citizens' rights cannot be undoubtedly claimed as the value of each state at all. For example, for states of slave-owning, feudal and bourgeois type, protection not only and not so much of human and citizen's rights and freedoms as defending the interests of a separate economically and politically dominant social class (slave-owners, feudal lords, capitalists) is more characteristic. In particular, the bourgeois states, which occupy a prominent place on the geopolitical map of the world, are characterized by the narrowing of their social base, economic and political monopoly, which leads to the recognition, assertion and protection of the interests of only the monopolistic bourgeoisie.

It is quite ambiguous to defend the rights of citizens in the aspect of the socialist state, the experience of practical construction of which even more recently undermined the authority of the ideology of socialism, among which values including the rule of rights and freedoms of man and citizen. In this case, scientists often adhere to diametrically opposite points of view. Certain thing is that this divergence in the characterization of the functions of the socialist state is caused, first of all, by a certain ideological dissonance, since on the one hand, the denial of the bourgeois theory of the rule of law leads to the denial and protection of the rights of citizens as its sign, which under conditions of the socialist capitalism cannot characterize a socialist state. Therefore, outside the field of Soviet ideology alone, the construction of the socialist state in its "pure" form, as well as the concept of the rule of law, requires recognition of the social significance and assurance of the rights and freedoms of the individual and citizen, their proper protection and protection by the socialist state.

At the same time, in our opinion, it would be more appropriate to speak not so much about the realities of the modern world as socialist states but as post-industrial states that embody capitalism imbued with ideas of the social value of each person, the guarantee, protection and reality of his rights and freedoms. In doing so, we must disagree with the definition of undemocratic regimes as regimes under which state power is exercised through the restriction and violation of formally proclaimed human rights and freedoms. First and foremost, undemocratic states are characterized by a violation not only of the formally proclaimed, but also, not least, of the natural rights and freedoms of man and citizen. Moreover, not only the facts of violation of such human rights are decisive, but also the absence of legal mechanisms and other guarantees for their implementation, an effective, state-guaranteed system of 
protection of human and citizen's rights and freedoms. And this is contrary to the essence of the rule of law, which underlies the rule of law and the mutual responsibility of the individual and the state.

Therefore, recognition, guarantee and, as a consequence, protection of human and citizen's rights and freedoms characterize a democratic state, since the wide and real participation of individuals and their associations in the organization of public and state life prevents possible violations of human rights, directs the activity of state institutions in the the channel of securing and protecting such human rights and freedoms. Of vital importance in substantiating the protection of the rights and freedoms of man and citizen, as an indispensable feature of the modern rule of law, is the concept of natural law, which is to some extent opposed to the theory of positive law. Accordingly, a state has no right to restrict the rights and freedoms of a person and a citizen, solely on the basis of a voluntary restriction of which, according to social contract theory, such a state does exist. That is why the public welfare should be a guideline in the activity of the state - the rights, freedoms and legitimate interests of the individual (not only natural but also acquired), ensuring the observance, realization and protection of which is the main social goal of the state.

On the other hand, the inferiority of law, its non-monopolization by the state proclaimed by the natural-law concept, directly determine the primacy of the right over the state, its connection not only by law, but also by natural human rights (which reflect human values), which embodies such a conceptual basis rule of law as the rule of law over the state.

At the same time, the protection of citizens' rights within the concept of positive law cannot be denied in full. It should be noted that the latter also adheres to the primacy of the right over the state, however, with the sole observation that such a right is conceived of as state law, which is formed by the state itself. Therefore, positivism implies that the respective rights and freedoms of the individual and the citizen will be subject to state protection, provided that they are legally enshrined and guaranteed, but completely limited by a positive law adopted by a state that is bound by nothing but its own in matters of the protection of citizens' rights.

Thus, the importance of the concepts of natural or positive law in protecting the rights of citizens is not so much in its substantive side as in substantiating the source of origin of human and citizen's rights and freedoms and protection as their binding legal guarantee. It should be noted that the protection of citizens' rights is directly related not only to the rule of law, but also to civil society, the main features of which are the control of power of the society, the person and his legitimate interests as the main value in society and the state, equality and equal protection of human rights in economic, spiritual and political spheres. Therefore, it is possible to speak about the commonality 
of civil society and the rule of law with such features as the recognition of human rights, freedoms and legitimate interests of the highest social value, general humanistic principles, state control of society, self-restraint of power, rule of law, mutual responsibility of the state and the individual. All this, in turn, lays the foundations for the protection of citizens' rights as a sign and a fundamental function of the rule of law.

Therefore, in the aspect of the protection of citizens' rights, it is necessary to establish a fairly close link between civil society and the rule of law. However, in science there is no single point of view regarding the relation between civil society and the rule of law, the priority and priority of one of these categories. We proceed from the fact that the phenomenon of the rule of law is such that positively contributes to the formation and development of civil society, acts as its political basis. It should be noted that the dialectical unity of civil society and the rule of law is expressed in the fact that the latter, on the one hand, determines, and on the other, itself determined by civil society. This is manifested in the unity of their features, in particular, in a somewhat generalized form it can be argued that the signs of the rule of law constitute a separate segment of civil society, which, at the level with the economic and spiritual basis, and determine its essence. In other words, the rule of law encompasses the political realm of civil society.

Civil society envisages a diversity of state-mediated relationships between free and equal individuals in a market environment and democratic rule of law. We emphasize that only a rule of law capable of self-restraint, guided by the rule of law in its activities, and recognizing, guaranteeing and protecting natural human rights, is truly capable of actually securing similar, unmediated social relations, freedom, equality and other rights of each human rights, the free formation and functioning of the economic sphere of society, democracy as a starting point for the management of public affairs. Thus, the formation of the rule of law is an integral element of civil society, which in turn also serves as a prerequisite for the effective functioning of the rule of law.

Thus, their unity, interconnectedness and interdependence, that is, both civil society and the rule of law, are different aspects of the same social reality. The protection of citizens' rights is not only one of the fundamental provisions of the rule of law as a political foundation of civil society, but is extrapolated in its economic and spiritual components.

Of particular importance is the fact that under the conditions of civil society, as in a democratic state based on the concept of natural law, a person has the right to demand from the state the protection of his rights, freedoms and legitimate interests. In other words, the protection of the rights and freedoms of the individual and the citizen is seen not as a privilege granted by the state, but as a natural right and a universal democratic value. And this, in turn, directly corresponds to the definition of the rule of law as "an 
organization of political power, whose activity is based on the recognition and real protection of human rights and freedoms, the rule of law and mutual responsibility of the individual and the state" ${ }^{20}$.

It should be noted that the protection of citizens' rights characterizes not only a democratic and rule of law in the conditions of civil society, but, as a consequence, also a social state as a post-industrial state. In general, in our opinion, the social nature of the state can be said, based primarily on the principle of social orientation of the state, the rule of law as the highest justice, the recognition of the priority of human rights and their freedoms, which is a clear expression of the protection of citizens' rights. At the same time, it should be noted that some scholars do not consider the protection of citizens' rights among the central features of the social and legal state separately. At the same time, it cannot be overlooked that the absence of an effective and efficient system of protection of human and citizen's rights and freedoms will testify to them, for the most part, only of a formal nature, under which it is not possible to speak of any social orientation of the state.

It should be emphasized that the rule of law, as a complex socio-legal phenomenon, can be characterized from different sides through the lens of many phenomena and processes. For example, in the political science dimension, the rule of law is defined as the legal form of organization and activity of public-political power, created on the basis of legitimacy, separation of powers, which builds its relations with citizens and society based on the presumption of the rule of law. In this regard, it should be noted that this definition is not sufficiently informative and does not reflect all the main features that make up the essence and content of the rule of law phenomenon, in particular, the place in the rule of law of rights and freedoms of a person and a citizen, their protection and protection are not revealed at all.

In general, there are at least two approaches to understanding the rule of law, which is considered either as a legal form of organization and exercise of political power, or as an appropriate sovereign political organization. At the same time, in the aspect of the researched issues of protection of the rights of citizens as a sign of the rule of law, we find it more expedient to define the signs and principles of the rule of law. So, first of all, it can be concluded that at the level with the principles of the rule of law, separation of powers, mutual responsibility of the individual and the state as an indispensable characteristic of the construction of the rule of law is also considered a priority of human and citizen rights and freedoms. At the same time, as we have already noted, the principle of the state's connection with the rights and freedoms of a person and a citizen is defined as essential in the understanding of the rule of law,

20 Загальна теорія держави i права: підручник [для студентів юридичних спеціальностей вищих навчальних закладів] / М.В. Цвік, В.Д. Ткаченко, Л.В. Авраменко та ін.; за ред. М.В. Цвіка, О.В. Петришина. - Х.: Право, 2009. - 584 с. 
since it is, in essence, an important factor of self-limitation of such a state and the formation of civil society.

On the other hand, as regards the rights and freedoms of man and citizen in relation to the rule of law, scholars tend to refer to their "recognition", "observance" and "realization". In our opinion, the participation of the rule of law should be somewhat broader and should consist not only of recognizing the legal definition of the exercise of human and citizen's rights and freedoms, but also of ensuring their reality. It should be noted that ensuring the reality of human and citizen's rights and freedoms requires the formation of special social and legal mechanisms for their realization, protection and protection. Therefore, in the absence of adequate measures to protect and protect against the prevention of violations and restoration of already violated rights of citizens, as well as the responsibility of perpetrators, there can be no question of a truly rule of law, since it violates the principles of mutual responsibility of the individual and the state, the priority of human rights and freedoms and citizen, social orientation of the state and the rule of law.

Therefore, the principle of ensuring the rights and freedoms of a person and a citizen by the state is considered to be properly included in the characteristic of the rule of law. At the same time, there is no consensus among scientists regarding the understanding of the concept and relation of these categories of protection and protection, including in relation to citizens' rights. It is noted that protection in a legal sense means a positive, static state of law, aimed directly at protecting the subjective rights and legitimate interests of citizens from possible offenses. In turn, the protection of citizens' rights is often interpreted as an active activity aimed at preventing, ending the offenses and restoring the violated rights of citizens.

In our opinion, the differentiation of categories of protection and protection matters except in the aspect of establishing their deep content and methods of implementation, while considering them in the perspective of features and functions of the rule of law, such differentiation is deprived of its principle, given the common purpose and essence of such varieties. ensuring the rights and freedoms of man and citizen.

Therefore, in this case, it is not entirely correct to claim that the primary purpose of protection is to prevent offenses, and remedies include both the restoration of violated rights, as well as the prevention of human rights violations, and their restoration, together with legal responsibility, all in their own right. collectively, serves the purpose of protecting the rights of citizens in the rule of law. Therefore, regarding the features and functions of the rule of law, the various mechanisms and forms of legal protection and protection of human and citizen's rights and freedoms are embodied in a holistic direction of state activity - protection of citizens 'rights, which is united by the focus of all means of the rule of law mechanism on ensuring the reality of citizens' rights. 
It should be noted that under this approach not only the protection but also the restoration of the violated rights and freedoms of the individual and the citizen are in fact distinguished from the protection of the rights of citizens, the content of which remains definitively uncertain. In fact, none of these elements of human and citizen's rights and freedoms can be said to be unrelated to their protection as a state guarantee of the reality of citizens' rights. Important in the aspect of the rule of law is the understanding and practical implementation of the protection of citizens' rights not only as one of its features, but also as a fundamental function of the rule of law. In general, the functions of the state are represented as the main directions and types of its activity, which express the essence and social purpose of such state in the sphere of public administration and state governance. It should be noted that we must distinguish between the general functions of each state as such (economic, political, defense function) and functions that directly derive from the basic socio-political, legal and spiritual principles and laws that underlie a particular state. The same applies to the functions of the modern democratic rule of law, which, as already stated, is a kind of product of the historical development of society and the state. Accordingly, it is possible to state at least such major functions of the rule of law as ensuring democracy, the rule of law and protecting the rights of citizens, which reflect the qualitative characteristics of the rule of law in comparison with other types of states. All of the above comes down to the category of the reality of human and citizen's rights and freedoms as the central and general goal of the rule of law, to which both democracy, the rule of law and the protection of citizens' rights are oriented. In other words, the protection and state of protection of citizens' rights as an indispensable factor of their reality in the rule of law is not isolated, but permeates all directions and spheres of state activity.

In this regard, first of all, it should be noted that the exercise of the protection of human and citizen's rights and freedoms is connected with the full existence of a person not just as a "being", but as an individual and a member of society. In addition, in our opinion, it should be not so much a "process of exercising rights and freedoms" as their actual reality and implementation as a result of state-guaranteed measures for the protection and protection of such rights and freedoms of man and citizen, which, respectively, is the purpose of this feature. However, in our opinion, this list of functional areas of protection of citizens' rights will be incomplete without including it and bringing the perpetrators to justice, as well as eliminating other negative social consequences. The latter is explained by the specific essence of the protection of the rights of citizens as the main function of the rule of law, which aims at restoring not only the ability of an individual to exercise their rights freely, but also the violation of social relations, the achievement of a certain social justice, including through means of legal responsibility and 
overcoming negative social consequences of violations of human and citizen's rights and freedoms. In addition, the definition of the protection of the rights and freedoms of the individual and the citizen must include its ultimate purpose, which is to ensure the full reality of such citizens' rights.

In addition, based on such features of the rule of law as the rule of law and the concept of natural law, it would be more right to characterize the protection of human and citizen's rights and freedoms as being exercised not so much in a "legal way" but in accordance with a non-monopolized state law. A separate issue of understanding the protection of citizens' rights as a feature and function of the rule of law concerns forms whose pluralism, in our opinion, is an essential characteristic of a full-fledged system of protection of human and citizen's rights and freedoms. One of the most accessible and rapid forms of protection of citizens' rights is the administrative and legal form. Yes, its essence is to apply measures of administrative coercion aimed at restoring, recognizing the rights and ending violations of citizens 'rights, committed by public authorities on citizens' declarations or at the initiative of competent authorities. At the same time, in the context of a modern democratic rule of law, the pluralistic nature of the protection of citizens' rights is of particular importance, which implies the equal functionality and effectiveness of all forms and methods of protection of human and citizen's rights and freedoms, the freedom of the citizen to choose and apply the forms of protection of his or her own. right.

Therefore, in summarizing the issues of understanding the function of the rule of law on the protection of citizens 'rights, we note that it should be understood as a system of measures to prevent violations of citizens' rights, control and supervision of their observance, confirm or restore the appealed or violated rights, ensure the legal liability of offenders and eliminate other negative social consequences of violations of citizens' rights implemented by organizational and legal means in accordance with the principles of the rule of law by public bodies Ada, public formations and citizens to ensure the reality of human rights.

The function of protection of the rights and freedoms of man and citizen, aimed at the realization of the social purpose of the rule of law, occupies a prominent place in the system of its functions, has systemic significance, extrapolating in all directions of the activity of the modern rule of law. Therefore, we emphasize the dialectical unity of the protection of the rights and freedoms of the individual and the citizen with all other features of the rule of law, which makes it possible to highlight the crucial role of the protection of the rights of citizens in the formation and functioning of the rule of law.

Thus, the protection of citizens' rights is in fact a complex multifaceted integrative feature and function of the modern state, while characterizing it through the lens of the structures of a democratic, legal and social state, 
natural law and civil society. All this testifies to the fundamental importance of protecting the rights of citizens for the social development and formation of a modern rule of law, ensuring and realizing its social purpose in guaranteeing the reality of human and citizen's rights and freedoms.

Administrative and legal protection is established with regard to the rights of citizens of Ukraine, foreigners and stateless persons, which covers not only the special, conditioned by the relevant public-legal status, but also the natural rights and freedoms of all individuals regardless of their citizenship. The essence and content of the principles of the legal status of a person and a citizen (inviolability, universality, universality, freedom, equality, dignity, justice), as well as guarantees of legal status, are determined precisely by human rights, the need to ensure their effective implementation.

The rights of the individual as an object of administrative and legal protection are characterized by the following basic features and properties: it is a multifaceted social phenomenon that covers legal, moral, political and philosophical content; it is a measure of possible behavior in concrete and historical conditions of social development; it is a fundamental element of the legal status of the individual, the inalienability of rights from duties; the conditionality and expression of the right, regardless of its specific form (not only in the legislation), as well as legal certainty and official character; the purpose is to meet the social needs of the individual in accordance with the law and order established in society and the state; providing the state with reality within the relevant specific legally formulated and socially justified and justified limits; the inseparability of subjective legal and natural rights from the process of their realization (use); protection by the state of individual rights.

Administrative and legal regulation is manifested in relation to all means and methods of administrative protection of citizens 'rights, defining the organization of the activity of executive bodies, which exercise the protection of citizens' rights; the procedure and cases of application of administrative coercion and administrative responsibility; the system of administrative justice and other procedural aspects directly related to the organization of administrative protection of human and citizen's rights and freedoms.

The priority areas of administrative and legal regulation should be the normative expression of the principles of coordination in the relations between state authorities and citizens, the formation of modern administrative and legal bases aimed at establishing the legal regime of real assistance to the state in the exercise and observance of human and citizen rights and freedoms, as well as the embodiment of relations in the system of protection of citizens' rights. In order to guarantee the true reality of the rights and freedoms of citizens under the rule of law, the provision of these relations of coordination with special means of administrative appeal and judicial protection of violated rights and freedoms of citizens is actualized. 
Concerning the category of public administration, the protection of citizens 'rights is conditionally made up of three segments - first, it is the organization of the system of protection of citizens' rights as an element of public administration (organization of activities of competent authorities, definition and organizational support of its legal mechanisms, control over the legitimacy of such protection), secondly, the coordination of the protection of citizens 'rights in public administration (between authorized public authorities and citizens), and third, the protection of citizens' rights outside the sphere of government governance (self-defense as a separate form of protection of citizens' rights).

\section{CONCLUSIONS}

The importance of the protection of citizens 'rights is manifested in their place in the general mechanism of protection of citizens' rights, in particular, in creating the conditions and ensuring the reality and effectiveness of existing forms and methods of protecting the rights, freedoms and legitimate interests of the individual and the citizen. Remedies are an indispensable element of preventing and ending violations, as well as restoring citizens' rights.

Means of protection of citizens 'rights are a complex of legal phenomena (instruments, measures, actions, etc.) carried out in accordance with the legislation in order to ensure the organization and implementation of protection of citizens' rights, including through the application and use of appropriate forms and methods of protection aimed at preventing and termination of violations, as well as restoration of rights, freedoms and legitimate interests of the individual and the citizen.

The system of administrative remedies consists of different in nature and purpose of legal phenomena, instruments, measures, actions carried out by different entities and at different stages of human rights activities, which jointly solve the problems of prevention and termination of violations, as well as restoration of rights, freedoms and the legitimate interests of the individual and the citizen. Systematic administrative remedies, in turn, requires not only their organic unity, but also a consistent combination and streamlining of administrative legal forms and methods of protection.

\section{REFERENCES}

1. Конституція України: від 28.06.1996 р., № 254к/96-ВР // ВВР України. - 1996. - № 30. - Ст. 141.

2. Турута О.В. Юридичний механізм забезпечення реальності прав і свобод громадян / О.В. Турута // Форум права. - 2010. - № 2. - С. 519-523 [Електронний ресурс]. - Режим доступу: http://www.nbuv.gov.ua/ e-journals/FP/2010-2/10tovicg.pdf. 
3. Волинка К. Забезпечення прав і свобод особи в Україні: теоретичні і практичні аспекти / К. Волинка // Право України. - 2000. № 11. - С. 30-34.

4. Колодій А.М. Права людини і громадянина в Україні: навч. посіб. / А.М. Колодій, А.Ю. Олійник. - К.: Юрінком Інтер, 2003. - 336 с.

5. Рабінович П.М. Основні права людини: поняття, класифікації, тенденції /П. М. Рабінович // Український часопис прав людини. 1995. - № 1. - С. 14-23.

6. Політичний енциклопедичний словник / за ред. Ю.М. Шемчушенка, В.Д. Бабкіна. - К.: Юрінком Інтер, 1997. - 512 с.

7. Радбрух Г. Філософія права / Г. Радбрух; пер. Є. Причепій, В. Приходько. - К.: Тандем, 2006. -316 с.

8. Кравченко В.В. Конституційне право України: навч. посіб. / В.В. Кравченко. - Вид. 4-е, випр. та доп. - К.: Атіка, 2007. - 568 с.

9. Загальна декларація прав людини: від 10.12.1948 р. // Офіційний вісник України. - 2008. - № 93. - Ст. 3103.

10. Рішення Конституційного Суду України у справі про призначення судом більш м’якого покарання: від 02.11.2004 p., № 15-рп/2004 // Офіційний вісник України. - 2004. - № 45. - Ст. 2975.

11. Рішення Конституційного Суду України у справі про охоронюваний законом інтерес: від 01.12.2004 р., № 18-рп/2004 // Офіційний вісник України. - 2004. - № 50. - Ст. 3288.

12. Загальна теорія держави і права: підручник [для студентів юридичних спеціальностей вищих навчальних закладів] / М.В. Цвік, В.Д. Ткаченко, Л.В. Авраменко та ін.; за ред. М.В. Цвіка, О.В. Петришина. - Х.: Право, 2009. - 584 с.

Information about the author: Sokolenko O. L., Doctor of Law, Professor, Dean of the Law Faculty, Oles Honchar Dnipro National University 